\title{
Study on Innovation of Securities Company's Asset Management Business
}

\author{
Xinyue Liu \\ Indiana University Bloomington, Franklin Hall 306, 601 East Kirkwood Avenue, Bloomington, IN \\ 47405-1223, USA \\ xinyue009@163.com
}

Keywords: Securities Company; Asset Management; Business Model; Innovation.

\begin{abstract}
Currently, asset management innovation is a substantially momentous topic of China's securities companies. With the challenges from research and development (R\&D) capability, product design, investment decision-making ability, risk control, organizational and institutional defects, China's securities have begun to focus on the business-model innovation, which is in terms of product innovation and management innovation, for accomplishing revenue growth and improving profit margins.
\end{abstract}

\section{Introduction}

The assets management business of China's securities company has been developed for about twenty years, but understanding of asset management is still in the shallow level. As the main development body of asset management, Securities companies should respond positively to the call of the national financial service economy, and conduct further asset management innovation. We need to draw on the management level and operational level of other assets management agencies abroad to make up for their deficiencies. Innovation is the source of all power, so Asset Management Business innovation is the best way to change the current situation for China's Securities companies. Innovative new products are described, and the improvements and advantages that they have are discussed.

\section{The Main Problems of Securities Company's Asset Management Business}

China's securities companies' asset management business development time is not too long, and there are many problems in various aspects. Some securities companies are faced with fierce competition and decline in traditional business profits.

The main problems of securities companies' asset management business are as follow:

a) Lack of R \& D capability of asset management business, resulting in product style and concept convergence, and abilities of risk diversification, portfolio design and pricing still need to be improved. The existing product development is relatively simple, lack of variety and individuality.

b) Unreasonable product design. Securities company asset management charge is unreasonable. Tend to pay too much attention to short-term gains, but not customer satisfaction, so it is not conducive to the normal long-term development of asset management business.

c) Inadequate asset management investment decision-making ability. Some management expert are not good enough in portfolio decision, financial markets observation, stock selection, so they cannot bring more profits to investors. Some investors even claim to replace manager, which brings adverse impact on the securities asset management.

d) Insufficient risk control. China's financial market is not fully mature, and most securities companies have not set up their own risk management and control system. When faced with the risks in actual operation, they are just dealing with their own experience; in prevention management process, they tend to focus on institutional risk or operational risk, and their management methods are very unscientific. 
e) Organizational and institutional defects. Asset management departments of China's securities companies do not operate completely independently, and the corresponding isolation system is not completely established, so the risk may be high. Coordination between departments is inefficient and unobstructed, leading to increased costs.

\section{Asset Management Business Innovation Model}

After a huge change in the domestic asset management market, some securities companies have begun to try to carry out business model innovation, in terms of product innovation and management innovation.

Product Innovation. It exists product homogeneity problem in securities companies' asset management business, resulting in lack of product features and affinity. Product innovation can be promoted from the perspective of product structure, investment style and customized demand innovation.

Product Structure. (1) Structured products. Structured products mainly carry on the risks and benefits redistribution of the same investment targets. There are mainly three kinds of innovative products in the market, including traditional revenue division products and new revenue division product; the former is to achieve the embedded option by classification, and subject matter of options is the net of the parent fund; the latter is improved that the subject matter other assets beyond the parent fund.

Case analysis - GF Kim Butler Leverage Collective Asset Management Plan. In 2013, GF Securities issued the only long-short two-way asset management plan in the market. This product has tripled lever, which can be considered as a product of pure tools. It includes mother share, bullish share and bearish share, to meet the needs of different investors. In terms of Investment scope, this product is nothing different from previous products, but its innovative product structure has earned it widespread market concerns.

Table 1. Description of GF Kim Butler Leverage Long-short Product

\begin{tabular}{|c|l|}
\hline \multicolumn{2}{|c|}{ GF Kim Butler Leverage Long-short Product } \\
\hline Product properties & \multicolumn{1}{c|}{ Large collection } \\
\hline Investment target & $\begin{array}{l}\text { Flexible and efficient use of account } \\
\text { funds; Relatively stable earnings; } \\
\text { according to index-linked settlement } \\
\text { rules, meet the requirements of the } \\
\text { client's leverage investment hedge }\end{array}$ \\
\hline Investment scope & $\begin{array}{l}\text { Fixed income assets: 0\% 95\%; cash } \\
\text { assets: 5\% 100\% }\end{array}$ \\
\hline Product advantage & $\begin{array}{l}\text { Providing long and short leveraged } \\
\text { investment vehicles; hierarchical } \\
\text { structure, suitable for different market } \\
\text { views; the freedom of choice; flexible } \\
\text { hedge }\end{array}$ \\
\hline
\end{tabular}

(2) Revenue compensated product. Revenue compensated products refer to that when investors subscribe and hold a period of compensation, if product annual yield less than the minimum income, the managers will bear its own funds benefits compensate for this part; if product annual yield more than the minimum income, then deduct the rate according to actual net worth and include it to investor returns. Its main innovation is to take fully advantage of the relaxed policy on proportion limit of brokers involved in the management plan of its own funds, and put this into a real good support for asset management business development.

Case analysis - Guotai Junan Securities Jundewen. Guotai Junan Securities Jundewen is a hybrid product market first with income compensation. It is well received by the market because of its 
innovative model that is not capped at the lowest interest rate, and it took only three days to raise one billion Yuan.

Since founded of this product, every three years is a revenue compensation period. Investors can hold this product from the beginning to end of revenue compensation period. The net value of holding assets can be calculated as follow:

a) When product annual yield in revenue compensation period < agreed annual yield, managers will make up for the loss of principal and principal compensation benefits, according to its own funds participating in the share corresponding assets.

b) When product annual yield in revenue compensation period $\geqslant$ agreed annual yield, calculate net asset value of the investors according to product net.

Investment Style. Quantitative hedging products are combination of the two concepts of "quantification" and "hedging". Quantitative investment is to apply computer to search for the "big probability" strategy of high yield from big data, and build the quantitative investment model by this strategy.

Huiquan quantify hedging 1 of State Securities is based on quantitative studies and fundamental studies. This product represents a direction of the market today, that is, to apply innovative quantitative stock-picking strategy.

Table 2. Description of Huiquan quantify hedging 1 of State Securities

\begin{tabular}{|c|c|}
\hline \multicolumn{2}{|c|}{ Huiquan quantify hedging 1 of State Securities } \\
\hline Product properties & Small collection \\
\hline Investment strategy & $\begin{array}{l}\text { Quantitative assessment + stock index } \\
\text { futures hedging }\end{array}$ \\
\hline Investment scope & $\begin{array}{l}\text { Stocks, bonds, securities investment } \\
\text { funds, central bank bills, short-term } \\
\text { financing bonds, asset-backed securities, } \\
\text { medium-term notes, stock index futures } \\
\text { and other financial derivatives; bond } \\
\text { repo, bank deposits and other financial } \\
\text { products. }\end{array}$ \\
\hline
\end{tabular}

Management Innovation. It exists product homogeneity problem in securities company's asset management business, resulting in lack of product features and affinity. Product innovation can be promoted from the perspective of product structure, investment style and customized demand innovation.

Securities-funds Cooperation. After the business model with cooperation between Securities Company and Bank or Trust, Securities companies now begin to cooperate with Sunshine private fund. Such cooperation is not a pure channel business, but Real cooperation between Securities Company and Sunshine private fund. With the help of brokers' asset management channel, sunshine private fund finally achieve the advantage complementary between hedging ability of brokers and stock picking ability private fund.

Table 3. Description of Junxiang Chongyang Alpha hedge 1 of Guotai Junan Securites

\begin{tabular}{|c|l|}
\hline \multicolumn{2}{|c|}{ Junxiang Chongyang Alpha hedge 1 of Guotai Junan Securites } \\
\hline Product properties & \multicolumn{1}{c|}{ Small collection } \\
\hline Investment target & $\begin{array}{l}\text { By establishing stock portfolio of equity } \\
\text { and fixed income securities, use hedging } \\
\text { instruments to manage systemic risk, so } \\
\text { that obtain long-term stable alpha returns. }\end{array}$ \\
\hline Administrator & $\begin{array}{l}\text { Shanghai Guotai Junan Securities Asset } \\
\text { Management Ltd. }\end{array}$ \\
\hline Research consultant & Shanghai Chongyang Investment Co., Ltd \\
\hline
\end{tabular}


Asset Management Subsidiary. Traditionally, asset management operations are carried out by the Securities companies' assets management department, but more and more Securities companies are conducting business management innovation in recent years. Some of the Securities companies try to learn from foreign models to set up asset management subsidiary to separate asset management business development. In China, Guotai Junan Securities, Haitong Securities, Everbright Securities, GF Securities, Orient Securities and many other Securities companies has set up a subsidiary of asset management.

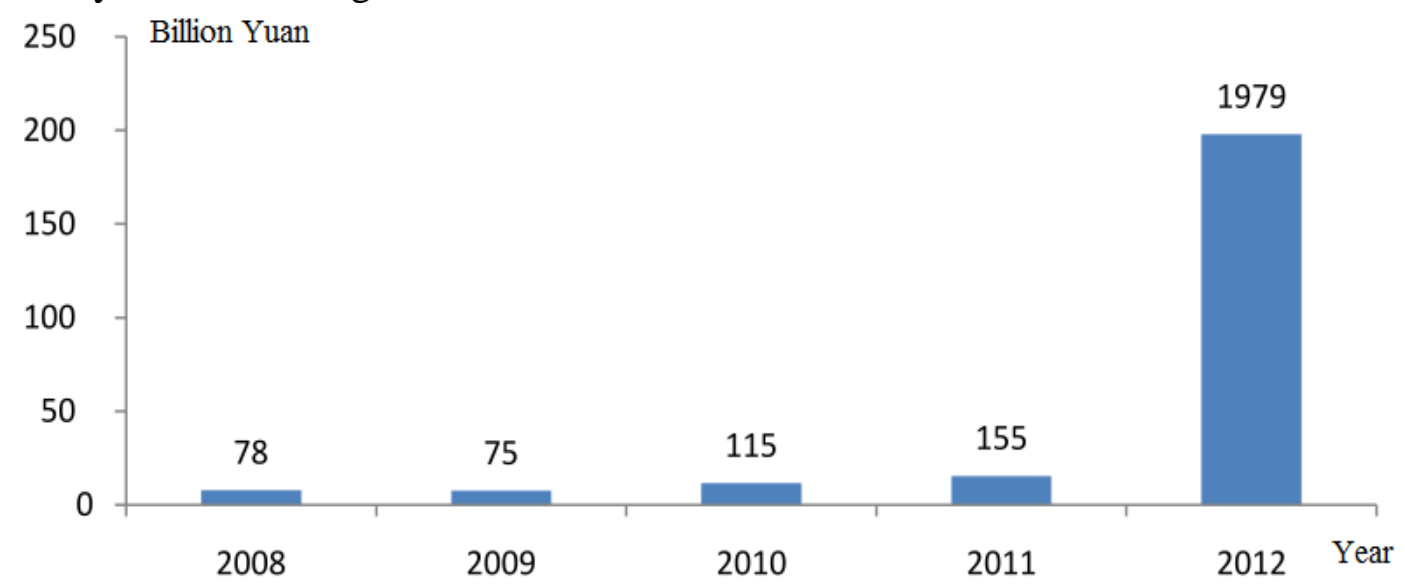

Fig. 1. The scale of asset management over the years of Guotai Junan Securities Table 4. Ranking of asset management scale of securities companies

\begin{tabular}{|c|c|c|c|c|}
\hline \multirow{2}{*}{ Rank } & \multirow{2}{*}{ Securities Company } & \multicolumn{3}{|c|}{ Scale of asset (Unit: billion Yuan ) } \\
\cline { 3 - 5 } & 2011 & 2012.06 & 2012.12 \\
\hline 1 & CITIC Securities & 62 & 71.8 & 250.8 \\
\hline 2 & Guotai Junan & 15.5 & 59.1 & 197.9 \\
\hline 3 & Hong Yuan Securities & 4.5 & 65.2 & 165.5 \\
\hline 4 & Everbright Securities & 9.1 & 16.5 & 91.6 \\
\hline 5 & $\begin{array}{c}\text { Shenyin \& Wanguo } \\
\text { Securities }\end{array}$ & 18.1 & 19.5 & 86 \\
\hline 6 & $\begin{array}{c}\text { CITIC construction } \\
\text { investment }\end{array}$ & n. a & n. a & 57.4 \\
\hline 7 & Huatai Securities & 8.3 & n. a & 52.3 \\
\hline 8 & Northeast Securities & n. a & n. a & 45.7 \\
\hline 9 & Essence Securities & 6 & n. a & 45.3 \\
\hline 10 & $\begin{array}{c}\text { Societe Generale } \\
\text { Securities }\end{array}$ & 6 & n. a & 44.4 \\
\hline
\end{tabular}

\section{References}

[1] X. Zhu, X. Zhan, W. Li, et al. The Discussion of the Development and Supervision Measures of Securities Company's Collective Asset Management Business. Securities Market Herald, 2012.

[2] X.Y. Yao, J.J. Shi. On the Scale Risk of Asset Management Business of Securities Companies in China. Journal of Xiangtan University, 2006.

[3] T. Wang. Research on the Assets Management Cooperation Pattern of Securities Companies in Pan Assets Management Era. Journal of Regional Financial Research, 2014.

[4] B. Ma. The Study on Product Innovation Ability of Small and Medium-sized Securities Company. Shanghai Finance, 2011.

[5] Allen, F and D. Gale. Financial Innovation And Risk Sharing, Cambridge, MA: MIT Press, 1994. 